\title{
New Targets for Therapy in Pancreatic Cancer
}

\author{
Nicola Tinari, Michele De Tursi, Antonino Grassadonia, \\ Marinella Zilli, Stefano Iacobelli and Clara Natoli \\ Dept. Oncology and Experimental Medicine, G. D'Annunzio University, Chieti-Pescara, \\ Italy
}

\section{Introduction}

Pancreatic ductal adenocarcinoma (PDAC) is the fourth cause of cancer-related death in the US, accounting for an estimated 37.000 in 2010 (Jemal et al., 2010). Only about $10-15 \%$ of newly diagnosed PDAC are potentially resectable, while the majority of patients present with locally advanced or metastatic cancer. The median survival of non operable patients treated with standard chemotherapy ranges between 3 and 10 months, with less than $20 \%$ alive at 1 year (Van Cutsem et al., 2004a). Survival rates have not substantially improved during the past 25 years, and gemcitabine, currently considered as the standard for the treatment of patients with advanced PDAC, only offers a limited advantage over 5fluorouracil. Moreover, in these patients the tolerance of chemotherapy is often limited, due to the frequent occurence of pain and poor performance status. Given the limited efficacy of conventional chemotherapy, there is an urgent need of new treatment options for this disease. It is now clear that development and progression of PDAC is a complex process involving alterations of a core set of signalling pathways implicated in the regulation of multiple processes such as proliferation, cell cycle, migration, invasion, metastatization, metabolism, angiogenesis and resistance to apoptosis (S. Jones et al., 2008).

This chapter will overview the more relevant cellular pathways involved in the development and progression of PDAC, and the results obtained in preclinical models and clinical trials with the use of novel agents specifically targeting them.

\section{Tyrosine kinases}

Proteins endowed with tyrosine kinase activity (TKs), i.e. able to transfer the terminal phosphate of ATP to the hydroxyl group of tyrosine on acceptor molecule, have long been established as key regulators of multiple cellular processes including cell growth, proliferation, migration, invasion and resistance to apoptosis. TKs include receptor tyrosine kinase (RTKs) and non-receptor TKs (NRTKs) (Natoli et al., 2010).

\subsection{RTKs}

RTKs are structurally divided in 20 subfamilies of single transmembrane alpha-helic proteins, with the exception of the IGFR family that retains a permanent dimeric 
conformation. The binding of a specific ligand to the extracellular domain of the receptor induces receptor dimerization and autophosphorylation at a regulatory tyrosine within the intracellular activation loop of the kinase. This triggers a cascade of intracellular reactions that mainly follows the p42/p44 mitogen-activated protein kinase (MAPK) and the phosphatidylinositol 3 kinase (PI3K)/protein kinase B (AKT) pathways, and culminates with the activation of genes involved in cell proliferation and survival.

\subsubsection{MAPK and PI3K/AKT pathways}

In the MAPK pathway a pivotal role is played by Ras proteins (k-Ras, N-Ras and H-Ras), enzymes with intrinsic GTPase activity (Ramos, 2008). Ras proteins are attached to the plasma membrane by virtue of farnesyl or geranylgeranyl chains covalently linked to their C-terminal end. These post-translational modifications are essential for membraneanchorage and function of Ras.

Following RTKs activation, a variety of proteins are recruited nearby the plasma membrane. The tyrosine phosphorylation of RTKs creates a specific binding site for the SH2 domain of adaptor proteins, such as Grb2, that in turn allows the recruitment of Guanine Nucleotide Exchange Factors (GEFs), such as SOS1. GEFs directly activate Ras by promoting the release of GDP and the binding of GTP. Activated (GTP-bound) Ras induces the activation of the Raf/MEK/MAPK signaling, and eventually of downstream transcription factors such as Jun/Fos.

The key regulator of the PI3K/AKT pathway is PI3K, an enzyme that phosphorylates the membrane lipid phosphatidyl inositol 4,5-P2 (PIP2) in 3,4,5-P3 (PIP3). PIP3 is then responsible for AKT activation (Osaki et al., 2004). A negative regulator of this pathway is the Phosphatase and Tensin homolog (PTEN), that switchs off the signalling by dephosphorylating PIP3 in PIP2.

PI3K is recruited to the plasma membrane by activated RTKs directly through its $\mathrm{SH} 2$ domain, or indirectly through adaptor proteins such as Grb2/Gab1, or IRS1/2 in the case of IGFR. Once PI3K is activated and PIP3 is produced, the serine-threonine kinase AKT and the phosphoinositide-dependent kinase 1 (PDK1) are co-recruited to the plasma membrane, resulting in the phosphorylation and activation of AKT by PDK1. Activated AKT is able to phosphorylate multiple downstream targets, such as BAD, MDM2 and mTOR. In particular, phoshorylation of mTOR activates many biological processes essential for angiogenesis, cell metabolism and proliferation (Dowling et al., 2010). AKT activates mTOR complex 1 (mTORC1) via the small GTPase, Rheb. In basal condition, Rheb activity is suppressed by the TSC1/TSC2 complex, a GTPase activating protein. AKT determines TSC2 phosphorylation and inhibition of TSC1/TSC2 function, changes that unleash Rheb activity and mTOR signalling. Once activated, mTOR increases mRNA translation via two major downstream targets: the eIF4E-binding proteins (4EBPs) and the S6 kinases (S6K1 and S6K2). The 4EBPs are suppressors of the initiation translation factor eIF4E. After phosphorylation by mTOR, 4EBPs release eIF4E and make it available for the assembling of the eIF4F initiation complex that activates mRNA translation. In addition, the phosphorylation of S6K determines the subsequent phosphorylation of the ribosomal protein S6, a component of the 40S ribosomal subunit, that further facilitates mRNA translation. Proteins encoded by "eIF4E-sensitive mRNAs" include VEGF, cyclins, c-Myc and Bcl-xl, molecules involved in angiogenesis, cell proliferation and survival. 


\subsection{NRTKs}

Based on structure, at least 10 subfamilies of NRTKs have been identified (Natoli et al., 2010). $\mathrm{ABL}$ and Src families have been particularly investigated for their implication in hematological and non-hematological malignancies. Physiologically, these proteins play a critical role in relaying intracellular signalling to the nucleus, regulating RTKs downstream signals, MAPK and PI3K/Akt, and several other key pathways, such as focal adhesion kinase (FAK) and signal transducers and activator of transcription (STAT transcription factors). NRTKs are maintained in an inactive state by intramolecular autoinhibition or by cellular inhibitor proteins or lipids. They are activated by diverse intracellular signals, including recruitment to RTK, dissociation of inhibitors, and trans-phosphorylation by other kinases. Activated NRTKs critically participate in the regulation of cell proliferation, differentiation, migration, adhesion, angiogenesis, invasion, and immune function.

\subsection{Dysregulation of TKs signalling in PDAC}

Given the central role of TKs in the regulation of cell growth and survival, it is not surprising that TKs and/or their downstream signalling mediators are aberrantly activated in different types of cancers, including PDAC.

In PDAC different RTKs have been shown to be frequently overexpressed, such as Epidermal Growth Factor Receptor (EGFR) in 90\% (Lemoine et al., 1992), HER2 in 45-70\% (Yamanaka et al., 1993b), Insulin-like Growth Factor-1 Receptor (IGF-1R) in about 50\% (Bergmann et al., 1995), and cMET in 70\% of the cases (M. Ebert et al., 1994). Overexpression is often reported to be associated with enhanced tumor growth, motility, invasion and drug resistance (M. Ebert et al., 1994; Freeman et al., 1995; Yamanaka et al., 1993a).

Consistent with RTKs overexpression, the downstream MAPK and PI3K/AKT pathways are often activated in PDAC. Activation of the MAPK pathway has been shown to be responsible for the malignant transformation of pancreatic cells (Matsuda et al., 2002). However, activation of Ras in PDCA is mostly RTK-independent, since activating mutations of this oncogene occur in about $90 \%$ of cases in advanced disease (Hruban, 2001). Because of an impaired GTPase activity, mutated Ras maintains a GTP-bound state, resulting in a continuous activation of the downstream Raf/MEK/MAPK signalling. Activating mutation of Raf has also been described in pancreatic cancer (Hruban, 2001).

Activation of PI3K/AKT pathway has been described in 50\% of PDAC cases and is associated with a worse prognosis (Schlieman et al., 2003). PI3K has been shown to stimulate proliferation and to be involved in drug resistance of pancreatic cancer cells (Perugini et al., 2000), while overexpression of AKT promotes invasion (Cheng et al., 1996) and expression of IGF-IR (Tanno et al., 2001).

Among NRTKs, aberrant Src activation has been described in multiple malignancies, including pancreatic cancer (Dehm \& Bonham, 2004), and shown to be related to increased cell motility and invasiveness (Shah \& Gallick, 2007).

The importance of TKs signalling in the maintenance of the neoplastic phenotype is emphasized by the fact that inhibition of these pathways induces cell-cycle arrest and apoptosis in preclinical models of pancreatic cancer (Asano et al., 2005; Bondar et al., 2002; Ng et al., 2002; Yip-Schneider \& Schmidt, 2003). 


\subsection{TKs therapeutic targeting}

Preclinical studies have shown dependency of pancreatic tumor cell proliferation upon TKs activity and tumor regression by its blockade.

In the last decade a number of molecules have been developed to inhibit TKs signalling. These agents can be divided into two major groups: small molecules that inhibit the catalytic activity of the kinase by interfering with the binding of ATP or substrates, and antibodies against RTKs or their ligands. In addition, other agents have been designed to block TKs' downstream signalling molecules, in particular Ras, Raf, MEK, AKT and mTOR. The most relevant anti-TKs strategies applied in PDCA are detailed below, along with ongoing clinical trials.

\subsubsection{Anti-EGFR therapies}

Cetuximab, a chimeric monoclonal antibody that targets the extracellular domain of human EGFR, has been tested in a phase III randomized trial by the Southwestern Oncology Group (SWOG trial S0205) in combination with gemcitabine in patients with unresectable, locally advanced or metastatic PDAC. The study showed no significant improvement in overall or progression-free survival with the addition of cetuximab, with a minimal although significant advantage in time-to-treatment-failure (Philip et al., 2010). A similar study design was used to test the efficacy of panitumumab, a humanized anti-EGFR antibody (clinicaltrial.gov: NCT00613730). The study was early terminated based on the results of the S0205 trial. A randomized phase II trial of panitumumab, erlotinib and gemcitabine vs. erlotinib and gemcitabine in patients with untreated, metastatic PDAC (clinicaltrial.gov: NCT00550836) has been recently completed and results are awaited.

Erlotinib, an EGFR tyrosine kinase inhibitor, has been tested in combination with gemcitabine in a randomized phase III trial (Moore et al., 2007). A very modest benefit in OS (median 6.24 vs 5.91 months, $\mathrm{P}=.038$ ) was observed compared with gemcitabine alone. Even if approved for the treatment of advanced PDAC, erlotinib is not routinely used because of increased toxicity and cost. Erlotinib is currently studied in the adjuvant setting (RTOG-led study 0848).

Other EGFR tyrosine kinase inhibitors, including gefitinb and lapatinib, have been tested in pilot studies, but failed to demonstrate a clinically significant activity (Brell et al., 2009; Ignatiadis et al., 2006; Safran et al., 2008).

\subsubsection{Anti-HER2 therapies}

Trastuzumab, a recombinant humanized antibody directed against HER2 and largely used in the treatment of HER2-positive breast cancer, has been tested in combination with gemcitabine in 34 PDAC patients with HER2-overexpressing tumors. No significant survival benefit was observed (Safran et al., 2004).

\subsubsection{Anti-IGF-1R therapies}

Several trials testing the safety and activity of inhibitors of IGF-1R are ongoing.

IMC-A12, an anti-IGF-1R monoclonal antibody, is currently being used in a randomized phase II study (SWOG 0727) in combination with chemotherapy and erlotinib in advanced 
PDAC. The dual block of IGF-1R and EGFR has a strong preclinical rationale since the inhibition of IGF-1R might reverse resistance to anti-EGFR agents (Camirand et al., 2005).

A study with the same design, carried out at the MD Anderson Cancer Center, is testing MK0646, a humanized monoclonal antibody against the IGF-1R (clinicaltrial.gov: NCT00769483).

Finally, AMG-479, another anti-IGF-1R antibody, is being used in combination with gemcitabine in a three-arm randomized phase II study. Preliminary results have been presented showing a trend toward longer PFS in the combination arm (Kindler et al., 2010a).

\subsubsection{Anti-c-MET therapies}

AMG-102, a fully humanized monoclonal antibody against c-MET, has been tested in a phase I study in patients with advanced solid tumors, including pancreatic cancer (Gordon et al., 2010). The drug was safe and well tolerated and it is going to be tested in a phase II study, in monotherapy or in combination with other agents.

\subsubsection{Anti-MAPK therapies}

Tipifarnib, a Ras inhibitor, has been studied in combination with gemcitabine in a randomized phase III clinical trial (Van Cutsem et al., 2004b). The combination has an acceptable toxicity profile, but does not prolong overall survival in advanced PDAC as compared with single-agent gemcitabine.

In a phase II study, Sorafenib, a TK inhibitor targeting Raf, VEGFR and PDGFR, has been tested in combination with gemcitabine in patients with advanced PDCA (Kindler et al., $2010 \mathrm{~b})$, but failed to demonstrate clinical benefit. Other Raf inhibitors are currently tested in clinical trials (W. W. Ma \& Adjei, 2009).

CI-1040, an oral MEK inhibitor, has been used in a pilot phase II study in advanced tumors, including PDAC. Although generally well tolerated, CI-1040 demonstrated insufficient antitumor activity to warrant further development (Rinehart et al., 2004).

\subsubsection{Anti-PI3K/AKT therapies}

Clinical experience with inhibitors of the PI3K/Akt pathway in PDAC is mostly limited to mTOR or AKT inhibitors. Everolimus and enzastaurin failed to demonstrate significant clinical activity when tested in gemcitabine-refractory (Wolpin et al., 2009) or advanced PDAC (Richards et al., 2011), respectively.

\subsubsection{Anti-Src therapies}

Among NRTK-inhibitors, AZD0530, a Src kinase inhibitor, is currently being tested in a phase II trial in gemcitabine resistant patients and in a phase I/II trial in combination with gemcitabine in unresectable disease (clinicaltrial.gov: NCT00735917).

\section{Angiogenesis}

Angiogenesis, the process by which new blood vessels are formed from pre-existing ones, is critical for the growth, progression and metastatization of solid tumors, including PDAC. 
This multistep process is tightly controlled by a fine-tuned balance between positive and negative regulators that emanate from cancer cells, endothelial cells, stromal cells, blood and the extracellular matrix.

Although several positive regulators of angiogenesis have been described, vascular endothelial growth factor (VEGF or VEGF-A) represents the prototypical pro-angiogenic factor (Ferrara et al., 2003). VEGF belongs to a gene family which includes placental growth factor (PLGF), VEGF-B, VEGF-C and VEGF-D. When released mainly by tumor cells, VEGF binds two specific receptor tyrosine kinases, VEGFR-1 (de Vries et al., 1992) and VEGFR-2 (Terman et al., 1992). This triggers receptor autophosphorylation and initiates a series of downstream signalling that promotes proliferation, survival and migration of endothelial cells.VEGFR-3 is also included in the same family of RTKs, but binds VEGF-C and VEGF-D (Karkkainen et al., 2002).

Overexpression of VEGF has been associated with tumor progression and poor prognosis in several tumor types. The increasingly recognized importance of VEGF signalling in promoting tumor angiogenesis has led to the development and clinical validation of several agent that selectively target this pathway. Today, inhibition of angiogenesis is considered a valid treatment approach in a number of solid tumours, although with limited efficacy (Carmeliet \& Jain, 2011).

Agents affecting the VEGF pathway include drugs targeting VEGF itself (antibodies or "traps") or the extracellular domain of VEGFR, small molecules targeting intracellular domains of VEGFR and those of other tyrosine kinases, and drugs inhibiting the intranuclear production of VEGFR mRNA, such as angiozyme.

Bevacizumab, a humanized monoclonal antibody with a high binding affinity for circulating vascular endothelial growth factor A (VEGF-A), has been demonstrated to enhance the response rate, progression-free and overall survival of patients with advanced cancer when added to various chemotherapeutic regimens. The cellular mechanisms of action of bevacizumab are multifactorial and include inhibition of vascular neogenesis, vascular regression and normalization of tumour vasculature (Ellis \& Hicklin, 2008). Several studies have shown that VEGF and its receptors are overexpressed in pancreatic cancer tissue and associated with liver metastases and poor prognosis (Kuehn et al., 1999; Seo et al., 2000). In PDAC, antiangiogenic therapy is still in an experimental phase with rare promising results. In the pre-clinical setting, inhibition of secreted VEGF by an antisense oligonucleotide led to decreased neoangiogenesis in a mouse xenograft model of pancreatic cancer resulting in reduced tumor growth and metastasis (Hotz et al., 2005). In the clinical setting, two randomized phase III trials of bevacizumab and gemcitabine (with or without erlotinib) failed to show any significant improvement of overall survival (Kindler et al., 2010c; Van Cutsem et al., 2009), and in one of them (Van Cutsem et al., 2009) only a marginal gain in progression-free survival was observed. The modest clinical benefit so far observed might be, at least in part, dependent on the development of resistance. Upregulation of compensatory angiogenic signalling pathways, such as those modulated by platelet-derived growth factor (PDGF) and fibroblast growth factor (FGF), has been suggested as a potential mechanism of resistance to anti-VEGF therapy (Casanovas et al., 2005).

As opposed to isolated VEGF/VEGFR inhibition, multitargeted antiangiogenic TK inhibitors may more completely inhibit angiogenesis by blocking overlapping pathways 
(Erber et al., 2004). A number of multitargeted antiangiogenic TK inhibitors are being tested in PDAC, including dual VEGFR/PDGFR and VEGFR/FGFR inhibitors (i.e. Sunitinib), as well as triple VEGFR/PDGFR/FGFR inhibitors (i.e. sorafenib), but limited activity in phase II trials ended further investigations on these agents.

Axitinib, an oral and selective inhibitor of VEGFR 1,2 and 3 and PDGFR- $\beta$, has been investigated in a phase II randomized trial in PDAC, associated with gemcitabine versus gemcitabine alone (Spano et al., 2008). The trial showed a small, non-statistically significant gain in overall survival for the combination arm. A randomized double-blind phase III trial with a similar design has been recently completed (Clinicaltrials.gov: NCT00471146) and results are awaited.

The persistent failure of anti-VEGF/VEGFR targeting in pancreatic cancer raises questions and concerns about choice of agents, trial design and our understanding of the biology of this disease.

\section{The hedgehog pathway}

The Hedgehog $(\mathrm{Hh})$ signalling controls the proper tissue formation or "patterning" during normal embryonic development, modulating cell migration, proliferation and differentiation (Ingham \& McMahon, 2001).

The Hh signalling is mediated by three secreted proteins with high degree of homology, known as Sonic Hh, Desert Hh and Indian Hh. These proteins act in an autocrine/ paracrine manner by binding the cellular transmembrane receptor Patched 1 (PTCH1). In the absence of the Hh ligand, PTCH1 inhibits the activity of another transmembrane protein, Smoothened (Smo), preventing its localization to the cell surface. After Hh binding, PTCH1 is internalized and degraded, allowing Smo to translocate to the cell membrane where it initiates a downstream signalling responsible for the release of the glioma-associated (Gli) proteins from the inhibitor complex Suppressor of Fused (SUFU). The subsequent activation and nuclear translocation of Gli transcriptional factors results in increased expression of genes encoding for growth factors, cell cycle regulators, cell adhesion molecules, matrix proteins, other transcription factors, and inhibitors of the Hh pathway itself (Cohen, 2010; Ruiz i Altaba et al., 2002).

A negative regulator of $\mathrm{Hh}$ pathway is Hh-interaction protein (HIP), a transmembrane protein that binds all $3 \mathrm{Hh}$ proteins and prevent ligand inactivation of PTCH1 (Chuang \& McMahon, 1999).

Increased expression of the Hedgehog pathway components has been demonstrated in PDAC and its precursor lesions, indicating a role of this pathway during early stages of tumorigenesis (Morton et al., 2007). Moreover, reduced or absent expression of HIP is related to Hh signalling activation in pancreatic cancer cell lines (Martin et al., 2005). In a recent microarray study, nineteen altered genes of the Hh pathway were identified and $100 \%$ of tumors had alterations in at least one of the Hh pathway genes (S. Jones et al., 2008).

Given the major role of Hh signalling in cancer development, the targeting of this pathway is considered a promising approach in the treatment of patients with PDCA. Indeed, in preclinical models, the inhibition of Hh signalling increased tumor cell apoptosis, decreased metastases, and significantly extended animal survival (Feldmann et al., 2008). 
Currently, a phase I/II clinical trial is evaluating IPI-926, a small molecule inhibitor of Smo, in combination with gemcitabine in patients with previously untreated metastatic PDAC. (ClinicalTrials.gov: NCT01130142). Other agents targeting various components of the Hh pathway are in preclinical or early clinical development, including Hh antagonist and Gli inhibitor.

\section{DNA repair mechanisms}

Mammalian cells are constantly exposed to exogenous (e.g. ultraviolet or ionising radiation and genotoxic chemicals) and endogenous (e.g. cellular metabolism and free radical generation) stresses responsible for DNA damage (Hoeijmakers, 2001). In order to preserve genomic integrity, cells are equipped with several DNA repair mechanisms, including nucleotide-excision repair (NER), base-excision repair (BER), mismatch repair (MMR), homologous recombination (HR) and non-homologous end-joining (NHEJ) pathways. Loss of function in one of these pathways determines an increased rate of chromosome breakage and, as a consequence, activation of oncogenes by translocations, inactivation of tumor suppressor genes by deletions and amplification of drug resistance genes, thus fostering tumor progression and drug resistance.

NER, BER and MMR pathways are involved in DNA single strand breaks (SSBs) repairing process, where the complementary DNA strand is intact and serves as a template (Hoeijmakers, 2001).

In particular, NER acts on damaged nucleotides that distort DNA helix, such as pyrimidine dimers induced by UV or adducts formed by chemotherapeutic agents. Interestingly, this pathway may confer resistance to platinum-based chemotherapy.

BER acts on nitrogenous bases damaged by reactive oxygen species or by spontaneous depurinations (Lindahl, 1993). Key enzymes in this pathway are PARP1 and PARP2, two nuclear proteins that catalyze the transfer of ADP-ribose units from intracellular NAD+ to nuclear acceptor proteins with the formation of ADP-ribose polymers.

MMR removes mispaired nucleotides derived from replication error ( $\mathrm{Li}, 2008)$ and is involved in the repair of DNA adducts such as those resulting from platinum-based chemotherapy (Kinsella, 2009). MMR pathway includes proteins encoded by different genes, such as MSH2, MSH3, MSH6, MLH1, MLH3, PMS1, and PMS2. It is noteworthy that an intact MMR pathway is required for cisplatin sensitivity, indicating a role for MMR proteins in the apoptotic signalling (Pani et al., 2007).

On the contrary, HR and NHEJ pathways are recruited in the case of DNA double-strand breaks (DSBs), which are devoid of a viable chromatid template (Hoeijmakers, 2001). HR acts using sister chromatid as template, and therefore it functions only during the late $S$ and G2 phases of the cell cycle, when a homologous region of DNA is available. HR repairs DNA DSBs caused by reactive oxygen species, ionizing radiation and certain antineoplastic drugs, such as bleomycin and anthracyclines. HR is initiated by the MRN complex which, thanks to its 3'-5' exonuclease activity, exposes the 3' ends on either side of the DSB (Zhong et al., 1999). Another complex, RPA, binds to the exposed single strand DNA to avoid degradation. Then, RAD51 is recruited at the site of DNA damage to initiate repair (Yu et 
al., 2003). BRCA1 and BRCA2, known for their implication in familial breast and ovarian cancers, play an important role in this pathway. BRCA1 is required to retain RPA at the sites of DSBs (Durant \& Nickoloff, 2005), while BRCA2 is required for RAD51 translocation (Yang et al., 2005).

NHEJ repairs DSBs during G1/S phase of the cell cycle. This pathway is activated by the DNA-dependent protein kinase Ku70/Ku80 and requires additional proteins, including the artemis protein and DNA ligase IV, for proper conclusion (Meek et al., 2004).

PDAC cells frequently harbor defects in DNA repair pathways, in particular as a result of BRCA2 or MMR gene mutation/deletion. BRCA2 mutation carriers have a 3-10-fold increased lifetime risk of developing PDAC (Shi et al., 2009). Germline BRCA2 gene mutations are responsible for approximately $10 \%$ of familial pancreatic cancer, whereas somatic mutations have been associated with $7-10 \%$ of sporadic PDAC (Shi et al., 2009).

The discovery that FANCD1, one of at least 13 Fanconi anemia (FA) proteins interacting in a common pathway involved in HR, is identical to BRCA2, resulted in a search for mutations in other FA genes as possible pancreatic-cancer risk genes. Recently, a pancreatic cancer susceptibility gene, PALB2 (FANCN), has been found to encode for a BRCA2-stabilizing protein (Tischkowitz et al., 2009) and a germline deletion in the PALB2 gene has been described in a patient with familial PDAC (S. Jones et al., 2009).

Alterations in the MMR genes have also been described in pancreatic cancer (Dong et al., 2011). A direct consequence of MMR impaired function is microsatellite instability that makes the genome vulnerable to other specific genetic alterations. However, tumors of the pancreas with microsatellite instability are relatively rare as compared to other malignancies of the digestive tract, and represent only $5 \%$ of PDAC.

Although abnormal DNA repair mechanisms critically contribute to tumor development and progression, they also provide a weakness that can be exploited therapeutically. In fact, tumors harboring defective DNA repair mechanisms might be particularly sensitive to DNA-damaging agents. For example, BRCA deficient cancer cells show increased sensitivity to agents causing DSBs, such as irradiation, mitomycin C, adriamycin, and cisplatin (Sonnenblick et al., 2011; van der Heijden et al., 2005). It has been shown that HR-deficient tumor cells, including those with defects in BRCA1/2, are highly sensitive to blockade of the BER pathway via inhibition of the PARP enzymes (Bryant et al., 2005; Farmer et al., 2005). In fact, PARP inhibitors (PARPis) lead to accumulation of SSBs that degenerate into stalled replication forks and, eventually, in DSBs, damage preferentially repaired by HR. Exposure of BRCA2-deficient murine tumors to PARPis resulted in a marked decrease in tumor growth and survival (Hay et al., 2009). A human pancreatic cancer cell line with defective BRCA2 function, CAPAN-1, has been shown to be very sensitive to the potent PARPis KU0058684 and KU0058948 (McCabe et al., 2005). The potential clinical application of PARP inhibition in BRCA2-related pancreatic cancer is encouraged by a recent published case report. A patient with a germline BRCA2 mutation affected by pancreatic cancer demonstrated a complete pathologic response after treatment with iniparib (BSI-201), a PARPi (Fogelman et al., 2011).

As expected, PARPis have also been shown to significantly enhance the cytotoxicity of chemotherapeutic agents, such as cisplatin and 5-fluorouracil (De Soto \& Mullins, 2011), and of radiotherapy (Tuli et al., 2011) in pancreatic cancer cell lines. 
A phase I/II study of the PARPi veliparib (ABT-888) in combination with chemotherapy (modified FOLFOX-6), is currently being conducted in patients with metastatic pancreatic cancer (Pishvaian et al., 2011). Another phase I study is testing the safety and tolerability of the PARPi olaparib (AZD2281) in combination with gemcitabine in PDAC (clinicaltrials.gov: NCT00515866). The same drug is being used as monotherapy in a phase II trial in patients with advanced cancers, including PDAC, with confirmed genetic BRCA1 and/or BRCA2 mutation (clinicaltrials.gov: NCT01078662).

\section{Histone deacetylase (HDACs)}

This large family of enzymes is composed of 18 members which are grouped into four classes according to their primary homology to similar yeast HDACs (de Ruijter et al., 2003). Classes I, II, and IV are structurally similar to the yeast proteins Hda1/Rpd3 and are zincdependent for their catalytic activity (de Ruijter et al., 2003), while class III HDACs include 7 different members of the sirtuin (SIRT) family and require NAD+ for their catalytic activity (Blander \& Guarente, 2004). These families differ for subcellular localization, catalytic activity and susceptibility to different inhibitors. HDACs are known to play a key role in the epigenetic regulation of gene expression (P. A. Jones \& Baylin, 2007). The process of deacetylation of histones by HDACs results in a closed chromatin structure, decreased access of transcription factors to promoter regions and repression of gene transcription leading to the silencing of tumor suppressor genes involved in cancer cell growth, differentiation and/or apoptosis (de Ruijter et al., 2003). Apart from regulating histone modification, HDACs also regulate the post-translational acetylation status of many nonhistone proteins involved in cancer cell proliferation, such as transcription factors, nuclear receptors and cytoskeletal proteins (Glozak et al., 2005).

Dysregulation of HDACs has been detected in hematological malignancies and several different types of solid tumors (Federico \& Bagella, 2011), including pancreatic cancer (Ouaissi et al., 2008; Ouaissi et al., 2011).

During the 1990s, a clear link between the suppression of tumor cell growth and survival and the inhibition of HDAC activity was established ( $\mathrm{Xu}$ et al., 2007), so that histone deacetylase inhibitors (HDACIs) have recently emerged as promising antineoplastic agents (Elaut et al., 2007). HDACIs can induce cell-cycle arrest, promote differentiation, and stimulate tumor cell death. Dimethyl sulfoxide (DMSO) and sodium butyrate $(\mathrm{NaBu})$ are the first chemical agents identified as HDACIs (Friend et al., 1971)

The preferential toxicity of HDAC inhibitors in transformed cells (Burgess et al., 2004; J. H. Lee et al., 2010) and their ability to synergistically enhance the anticancer activity of many chemotherapeutic agents (Sigalotti et al., 2007) has generated a great deal of interest in developing new HDACIs for cancer therapy. Indeed, several compounds, including panHDAC inhibitors and class-selective or isoform-selective HDACIs, have been synthesized and tested in phase I, II and III clinical trials in cancer patients, either alone or in combination with other chemotherapeutic agents.

Currently, two HDACIs are available for cancer treatment, suberoylanilide hydroxamic acid (SAHA or Vorinostat) (Vrana et al., 1999) and romidepsin (Khan et al., 2004) which have been approved by FDA for the treatment of cutaneous T-cell lymphoma. Vorinostat as well 
as other HDACI such as Entinostat (MS-275) (Gojo et al., 2007) and MGCD0103 (Kell, 2007) both of them in clinical trials (Kell, 2007; Tomillero \& Moral, 2010) - have been shown to exert proapoptotic effects on pancreatic tumor cells and to chemosensitize them to gemcitabine (Arnold et al., 2007; Iwahashi et al., 2011; Sung et al., 2011). These drugs are now being tested in phase I-II trials recruiting advanced pancreatic cancer patients.

\section{Checkpoint kinase-1 (Chk1)}

The Chk1, downstream the nuclear protein kinase ataxia-telangiectasia mutated -ATM(Kurz \& Lees-Miller, 2004), arrests cells in the S- and G2-phases of the cell cycle in the presence of replication stress or DNA double-strand breaks, thus allowing cells to repair the damage (Koniaras et al., 2001). When this mechanism is defective, cells accumulate DNA damages which lead to apoptosis. p53-deficient cancer cells, rely on CHK1 for the damage response and agents able to disrupt this pathway could induce a specialized form of cell death known as mitotic catastrophe.

Inhibitors of the Chk1 are currently in development with the aim to improve the efficacy and selectivity of a variety of DNA-damaging agents or antimetabolites (Bolderson et al., 2009; Du et al., 2011; C. X. Ma et al., 2011). Recently, novel Chk1 inhibitors, such as AZD7762, have been shown to be able to sensitize pancreatic cancer cells and tumors to gemcitabine and are now in Phase I clinical trials (Morgan et al., 2010; Parsels et al., 2011)

\section{8. microRNAs}

Two main classes of RNAs are known: messenger RNAs (mRNAs), which are translated into proteins, and non-protein-coding RNAs (ncRNAs), whose function has been related to the regulation of intracellular and extracellular signalling involved in cell differentiation and development (Amaral \& Mattick, 2008; Dinger et al., 2008).

The following molecules have been included in the group of ncRNAs:

- long ncRNAs, longer than 100 nucleotides, with a positive effect on regulation of gene expression (Orom et al., 2010);

- small nucleolar RNAs (snoRNAs), able to modify or guide the pseudouridylation or the methylation of other RNAs (Mallardo et al., 2008);

- $\quad$ small interfering RNAs (siRNA), regulating gene expression post-transcriptionally, by silencing specific mRNA molecules (J. Wang et al., 2010);

- $\quad$ piwi-interacting RNAs (piRNA), involved in the silencing of retrotransposons in germ cells

- $\quad$ riboswitches, a part of RNA that binds small molecule ligands (Siomi et al., 2011);

- microRNAs (miRNAs), small (18-24 nucleotide in lenght) single stranded RNA molecules that negatively regulate gene expression (Bartel, 2004).

Among all these regulatory ncRNSa, miRNAs are now acquiring a major relevance as potential therapeutic targets. miRNA were first discovered in Caenorhabditis elegans (R. C. Lee et al., 1993) and subsequently shown to be evolutionarily conserved genes (Moss, 2007), more than 1000 miRNAs being so far identified (miRBase database, release 17). 
The biogenesis pathway of miRNA in animal cells is a complex multi-step process starting in the nucleus and (through many post-transcriptional modifications) ending in the cytoplasm to generate the mature, single stranded miRNA (Huang et al., 2011). miRNAs silence gene expression by binding to the 3'UTR of the target mRNAs with imperfect complementarity, thus causing repression of translation or inducing target mRNA molecule degradation, with consequent reduction or loss of the protein product (Carthew \& Sontheimer, 2009; Huntzinger \& Izaurralde, 2011).

miRNAs have been shown to be missing or down-regulated in a variety of medical conditions including cancer, diabetes, and cardiovascular diseases (Medina \& Slack, 2008; Z. Wang et al., 2011). For their role in cancer initiation and/or progression, miRNAs have been included in the family of genes recognized as tumor suppressors and oncogenes, with the name of oncomiRs or anti-oncomiRs (Iorio \& Croce, 2009; Kent \& Mendell, 2006). Moreover, because of these critical functions in the regulation of signalling pathways, miRNAs are regarded as new promising therapeutic targets for cancer treatment (Bader et al., 2011).

Direct therapeutic approaches are based on the development of new drugs able to modulate miRNA expression levels, including:

- miRNA mimics, to inhibit the expression of target protein-coding genes, for miRNAs whose expression is reduced in diseases (Kota et al., 2009)

- miRNA inhibitors, with antisense constructs like antagomiRs, to increase gene expression (M. S. Ebert et al., 2007)

However, there are still many problems to be solved, such as stability, effective in vivo delivery systems, and selectivity.

These therapeutic strategies could be of high relevance for pancreatic cancer treatment. Recently, deregulation of miRNAs expression has been correlated to diagnosis, prognosis and chemotherapy resistance of pancreatic cancer (Chakraborty et al., 2011; Dhayat et al., 2011). Among the several miRNAs reported to be up regulated in pancreatic cancer such as miR-21, miR-221/222, miR-25, miR-27a, miR-210, miR-200b, miR-148a,b, miR-196a-2, miR-155, and members of the miR-17-92 family (Chakraborty et al., 2011; Liffers et al., 2011; Nana-Sinkam \& Croce, 2011; Zhang et al., 2011), the oncomiR miR-21 appears of high relevance as potential therapeutic target in pancreatic cancer, regulating proliferation, invasion, apoptosis and chemosensitivity (Ali et al., 2010; Giovannetti et al., 2010; Hwang et al., 2010; Park et al., 2009). miR-21 mimics, transfected into MIA PaCa-2 pancreatic cancer cells, have been shown to upregulate Bcl-2, to downregulate Bax expression, to decrease chemosensitivity to gemcitabine and to increase proliferation as compared with control cells. Transfection with miR-21 inhibitors had opposite effects, decreasing cell proliferation (J. Dong et al., 2011).

Further, miRNA-based biomarkers have a significant impact on the development of treatment strategy that combines therapeutics with diagnostics, a concept known as theranostics (Pene et al., 2009) and are highly relevant for drug development and personalized medicine.

\section{Conclusion}

In the last decade, a variety of molecularly targeted agents potentially useful in the treatment of PDAC have been developed. However, in contrast with the encouraging results 
obtained in animal models, results in humans have been quite disappointing. The still limited knowledge of the molecular pathogenesis of PDAC, the inappropriateness of the experimental models, the suboptimal combinations and schedules selected for clinical trials can be suggested as possible reasons for this failure. Given the complexity of the molecular pathogenesis of PDAC, it is very likely that a substantial improvement of clinical outcome can derive from the rational targeting of more than a single altered pathway.

\section{References}

Ali, S., Ahmad, A., Banerjee, S., Padhye, S., Dominiak, K., Schaffert, J.M., Wang, Z., Philip, P.A. \& Sarkar, F.H. (2010). Gemcitabine sensitivity can be induced in pancreatic cancer cells through modulation of miR-200 and miR-21 expression by curcumin or its analogue CDF. Cancer Res, Vol. 70, No.9, (May 2010), pp. 3606-3617, ISSN: 15387445

Amaral, P.P. \& Mattick, J.S. (2008). Noncoding RNA in development. Mammalian Genome, Vol. 19, No.7-8, pp. 454-492, ISSN: 0938-8990.

Arnold, N.B., Arkus, N., Gunn, J. \& Korc, M. (2007). The histone deacetylase inhibitor suberoylanilide hydroxamic acid induces growth inhibition and enhances gemcitabine-induced cell death in pancreatic cancer. Clin Cancer Res, Vol. 13, No.1, (January 2007), pp. 18-26, ISSN: 1078-0432

Asano, T., Yao, Y., Zhu, J., Li, D., Abbruzzese, J.L. \& Reddy, S.A. (2005). The rapamycin analog CCI-779 is a potent inhibitor of pancreatic cancer cell proliferation. Biochem Biophys Res Commun, Vol. 331, No.1, (May 2005), pp. 295-302, ISSN: 0006-291

Bader, A.G., Brown, D., Stoudemire, J. \& Lammers, P. (2011). Developing therapeutic microRNAs for cancer. Gene Ther, (June 2011), pp. ISSN: 0969-7128

Bartel, D.P. (2004). MicroRNAs: genomics, biogenesis, mechanism, and function. Cell, Vol. 116, No.2, (January 2004), pp. 281-297, ISSN: 0092-8674

Bergmann, U., Funatomi, H., Yokoyama, M., Beger, H.G. \& Korc, M. (1995). Insulin-like growth factor I overexpression in human pancreatic cancer: evidence for autocrine and paracrine roles. Cancer Res, Vol. 55, No.10, (May 1995), pp. 2007-2011, ISSN: 0008-5472

Blander, G. \& Guarente, L. (2004). The Sir2 family of protein deacetylases. Annu Rev Biochem, Vol. 73, pp. 417-435, ISSN: 0066-4154

Bolderson, E., Richard, D.J., Zhou, B.B. \& Khanna, K.K. (2009). Recent advances in cancer therapy targeting proteins involved in DNA double-strand break repair. Clin Cancer Res, Vol. 15, No.20, (October 2009), pp. 6314-6320, ISSN: 1078-0432

Bondar, V.M., Sweeney-Gotsch, B., Andreeff, M., Mills, G.B. \& McConkey, D.J. (2002). Inhibition of the phosphatidylinositol 3'-kinase-AKT pathway induces apoptosis in pancreatic carcinoma cells in vitro and in vivo. Mol Cancer Ther, Vol. 1, No.12, (October 2002), pp. 989-997, ISSN: 1535-7163

Brell, J.M., Matin, K., Evans, T., Volkin, R.L., Kiefer, G.J., Schlesselman, J.J., Dranko, S., Rath, L., Schmotzer, A., Lenzner, D. \& Ramanathan, R.K. (2009). Phase II study of docetaxel and gefitinib as second-line therapy in gemcitabine pretreated patients with advanced pancreatic cancer. Oncology, Vol. 76, No. 4, (March 2009), pp. 270-4, ISSN: 0030-2414

Bryant, H.E., Schultz, N., Thomas, H.D., Parker, K.M., Flower, D., Lopez, E., Kyle, S., Meuth, M., Curtin, N.J. \& Helleday, T. (2005). Specific killing of BRCA2-deficient tumours 
with inhibitors of poly(ADP-ribose) polymerase. Nature, Vol. 434, No.7035, (April 2005), pp. 913-917, ISSN: 0028-0836.

Burgess, A., Ruefli, A., Beamish, H., Warrener, R., Saunders, N., Johnstone, R. \& Gabrielli, B. (2004). Histone deacetylase inhibitors specifically kill nonproliferating tumour cells. Oncogene, Vol. 23, No.40, (September 2004), pp. 6693-6701, ISSN: 0950-9232

Camirand, A., Zakikhani, M., Young, F. \& Pollak, M. (2005). Inhibition of insulin-like growth factor-1 receptor signalling enhances growth-inhibitory and proapoptotic effects of gefitinib (Iressa) in human breast cancer cells. Breast Cancer Res, Vol. 7, No.4, (April 2005), pp. R570-579, ISSN: 1465-5411

Carmeliet, P. \& Jain, R.K. (2011). Molecular mechanisms and clinical applications of angiogenesis. Nature, Vol. 473, No.7347, (May 2011), pp. 298-307, ISSN: 0028-0836

Carthew, R.W. \& Sontheimer, E.J. (2009). Origins and Mechanisms of miRNAs and siRNAs. Cell, Vol. 136, No.4, (February 2009), pp. 642-655, ISSN: 00928674

Casanovas, O., Hicklin, D.J., Bergers, G. \& Hanahan, D. (2005). Drug resistance by evasion of antiangiogenic targeting of VEGF signalling in late-stage pancreatic islet tumors. Cancer Cell, Vol. 8, No.4, (October 2005), pp. 299-309, ISSN: 1535-6108

Chakraborty, S., Baine, M.J., Sasson, A.R. \& Batra, S.K. (2011). Current status of molecular markers for early detection of sporadic pancreatic cancer. Biochim Biophys Acta, Vol. 1815, No.1, (January 2011), pp. 44-64, ISSN: ISSN: 0006-3002

Cheng, J.Q., Ruggeri, B., Klein, W.M., Sonoda, G., Altomare, D.A., Watson, D.K. \& Testa, J.R. (1996). Amplification of AKT2 in human pancreatic cells and inhibition of AKT2 expression and tumorigenicity by antisense RNA. Proc Natl Acad Sci U S A, Vol. 93, No.8, (April 1996), pp. 3636-3641, ISSN: 0027-8424

Chuang, P.T. \& McMahon, A.P. (1999). Vertebrate Hedgehog signalling modulated by induction of a Hedgehog-binding protein. Nature, Vol. 397, No.6720, (February 1999), pp. 617-621, ISSN: 0028-0836

Cohen, M.M., Jr. (2010). Hedgehog signalling update. Am J Med Genet A, Vol. 152A, No.8, (August 2010), pp. 1875-1914, ISSN: 1552-4833

de Ruijter, A.J., van Gennip, A.H., Caron, H.N., Kemp, S. \& van Kuilenburg, A.B. (2003). Histone deacetylases (HDACs): characterization of the classical HDAC family. Biochem J, Vol. 370, No.Pt 3, (March 2003), pp. 737-749, ISSN: 0264-6021

de Vries, C., Escobedo, J.A., Ueno, H., Houck, K., Ferrara, N. \& Williams, L.T. (1992). The fms-like tyrosine kinase, a receptor for vascular endothelial growth factor. Science, Vol. 255, No.5047, (February 1992), pp. 989-991, ISSN: 0036-8075

Dehm, S.M. \& Bonham, K. (2004). SRC gene expression in human cancer: the role of transcriptional activation. Biochem Cell Biol, Vol. 82, No.2, (April 2004), pp. 263-274, ISSN: 0829-8211

De Soto, J.A. \& Mullins, R. (2011). The use of PARP inhibitors as single agents and as chemosensitizers in sporadic pancreatic cancer. Proceedings of the ASCO Annual Meeting, ISSN: 0732-183X, Chicago, June 2011

Dhayat, S., Mardin, W.A., Mees, S.T. \& Haier, J. (2011). Epigenetic markers for chemosensitivity and chemoresistance in pancreatic cancer-A review. Int J Cancer, Vol. 129, No.5, (September 2011), pp. 1031-1041, ISSN: 0020-7136

Dinger, M.E., Mercer, T.R. \& Mattick, J.S. (2008). RNAs as extracellular signalling molecules. Journal of Molecular Endocrinology, Vol. 40, No.4, (April 2008), pp. 151-159, ISSN: 1479-6813 
Dong, J., Zhao, Y.P., Zhou, L., Zhang, T.P. \& Chen, G. (2011). Bcl-2 upregulation induced by miR-21 via a direct interaction is associated with apoptosis and chemoresistance in MIA PaCa-2 pancreatic cancer cells. Arch Med Res, Vol. 42, No.1, (January 2011), pp. 8-14, ISSN: 0188-4409

Dong, X., Li, Y., Chang, P., Hess, K.R., Abbruzzese, J.L. \& Li, D. (2011). DNA mismatch repair network gene polymorphism as a susceptibility factor for pancreatic cancer. Mol Carcinog, (June 2011), ISSN: 0899-1987.

Dowling, R.J., Topisirovic, I., Fonseca, B.D. \& Sonenberg, N. (2010). Dissecting the role of mTOR: lessons from mTOR inhibitors. Biochim Biophys Acta, Vol. 1804, No.3, (March 2010), pp. 433-439, ISSN: 0006-3002

Du, J., Sun, H., Xi, L., Li, J., Yang, Y., Liu, H. \& Yao, X. (2011). Molecular modeling study of checkpoint kinase 1 inhibitors by multiple docking strategies and prime/MMGBSA calculation. J Comput Chem, (Jun 2011), ISSN: 1096-987X

Durant, S.T. \& Nickoloff, J.A. (2005). Good timing in the cell cycle for precise DNA repair by BRCA1. Cell Cycle, Vol. 4, No.9, (September 2005), pp. 1216-1222, ISSN: 1551-4005

Ebert, M., Yokoyama, M., Friess, H., Buchler, M.W. \& Korc, M. (1994). Coexpression of the cmet proto-oncogene and hepatocyte growth factor in human pancreatic cancer. Cancer Res, Vol. 54, No.22, (November 1994), pp. 5775-5778, ISSN: 0008-5472

Ebert, M.S., Neilson, J.R. \& Sharp, P.A. (2007). MicroRNA sponges: competitive inhibitors of small RNAs in mammalian cells. Nat Methods, Vol. 4, No.9, (September 2007), pp. 721-726, ISSN: $1548-7091$

Elaut, G., Rogiers, V. \& Vanhaecke, T. (2007). The pharmaceutical potential of histone deacetylase inhibitors. Curr Pharm Des, Vol. 13, No.25, (September 2007), pp. 25842620, ISSN: 1381-6128 (Linking)

Ellis, L.M. \& Hicklin, D.J. (2008). VEGF-targeted therapy: mechanisms of anti-tumour activity. Nat Rev Cancer, Vol. 8, No.8, (August 2008), pp. 579-591, ISSN: 1474-175X

Erber, R., Thurnher, A., Katsen, A.D., Groth, G., Kerger, H., Hammes, H.P., Menger, M.D., Ullrich, A. \& Vajkoczy, P. (2004). Combined inhibition of VEGF and PDGF signalling enforces tumor vessel regression by interfering with pericyte-mediated endothelial cell survival mechanisms. FASEB J, Vol. 18, No.2, (February 2004), pp. 338-340, ISSN: 0892-6638

Farmer, H., McCabe, N., Lord, C.J., Tutt, A.N., Johnson, D.A., Richardson, T.B., Santarosa, M., Dillon, K.J., Hickson, I., Knights, C., Martin, N.M., Jackson, S.P., Smith, G.C. \& Ashworth, A. (2005). Targeting the DNA repair defect in BRCA mutant cells as a therapeutic strategy. Nature, Vol. 434, No.7035, (April 2005), pp. 917-921, ISSN: 0028-0836.

Federico, M. \& Bagella, L. (2011). Histone deacetylase inhibitors in the treatment of hematological malignancies and solid tumors. J Biomed Biotechnol, Vol. 2011, ISSN: $1110-7243$

Feldmann, G., Habbe, N., Dhara, S., Bisht, S., Alvarez, H., Fendrich, V., Beaty, R., Mullendore, M., Karikari, C., Bardeesy, N., Ouellette, M.M., Yu, W. \& Maitra, A. (2008). Hedgehog inhibition prolongs survival in a genetically engineered mouse model of pancreatic cancer. Gut, Vol. 57, No.10, (October 2008), pp. 1420-1430, ISSN: 0017-5749

Ferrara, N., Gerber, H.P. \& LeCouter, J. (2003). The biology of VEGF and its receptors. Nat Med, Vol. 9, No.6, (June 2003), pp. 669-676, ISSN: 1078-8956 
Fogelman, D.R., Wolff, R.A., Kopetz, S., Javle, M., Bradley, C., Mok, I., Cabanillas, F. \& Abbruzzese, J.L. (2011). Evidence for the efficacy of Iniparib, a PARP-1 inhibitor, in BRCA2-associated pancreatic cancer. Anticancer Res, Vol. 31, No.4, (April 2011), pp. 1417-1420, ISSN: 0250-7005

Freeman, J.W., Mattingly, C.A. \& Strodel, W.E. (1995). Increased tumorigenicity in the human pancreatic cell line MIA PaCa-2 is associated with an aberrant regulation of an IGF-1 autocrine loop and lack of expression of the TGF-beta type RII receptor. $J$ Cell Physiol, Vol. 165, No.1, (October 1995), pp. 155-163, ISSN: 0021-9541

Friend, C., Scher, W., Holland, J.G. \& Sato, T. (1971). Hemoglobin synthesis in murine virusinduced leukemic cells in vitro: stimulation of erythroid differentiation by dimethyl sulfoxide. Proc Natl Acad Sci U S A, Vol. 68, No.2, (February 1971), pp. 378-382, ISSN: 0027-8424

Giovannetti, E., Funel, N., Peters, G.J., Del Chiaro, M., Erozenci, L.A., Vasile, E., Leon, L.G., Pollina, L.E., Groen, A., Falcone, A., Danesi, R., Campani, D., Verheul, H.M. \& Boggi, U. (2010). MicroRNA-21 in pancreatic cancer: correlation with clinical outcome and pharmacologic aspects underlying its role in the modulation of gemcitabine activity. Cancer Res, Vol. 70, No.11, (June 2010), pp. 4528-4538, ISSN: 0008-5472

Glozak, M.A., Sengupta, N., Zhang, X. \& Seto, E. (2005). Acetylation and deacetylation of non-histone proteins. Gene, Vol. 363, (December 2005), pp. 15-23, ISSN: 0378-1119

Gojo, I., Jiemjit, A., Trepel, J.B., Sparreboom, A., Figg, W.D., Rollins, S., Tidwell, M.L., Greer, J., Chung, E.J., Lee, M.J., Gore, S.D., Sausville, E.A., Zwiebel, J. \& Karp, J.E. (2007). Phase 1 and pharmacologic study of MS-275, a histone deacetylase inhibitor, in adults with refractory and relapsed acute leukemias. Blood, Vol. 109, No.7, (April 2007), pp. 2781-2790, ISSN: 0006-4971

Gordon, M.S., Sweeney, C.S., Mendelson, D.S., Eckhardt, S.G., Anderson, A., Beaupre, D.M., Branstetter, D., Burgess, T.L., Coxon, A., Deng, H., Kaplan-Lefko, P., Leitch, I.M., Oliner, K.S., Yan, L., Zhu, M. \& Gore, L. (2010). Safety, pharmacokinetics, and pharmacodynamics of AMG 102, a fully human hepatocyte growth factorneutralizing monoclonal antibody, in a first-in-human study of patients with advanced solid tumors. Clin Cancer Res, Vol. 16, No.2, (January 2010), pp. 699-710, ISSN: 1078-0432

Hay, T., Matthews, J.R., Pietzka, L., Lau, A., Cranston, A., Nygren, A.O., Douglas-Jones, A., Smith, G.C., Martin, N.M., O'Connor, M. \& Clarke, A.R. (2009). Poly(ADP-ribose) polymerase-1 inhibitor treatment regresses autochthonous Brca2/p53-mutant mammary tumors in vivo and delays tumor relapse in combination with carboplatin. Cancer Res, Vol. 69, No.9, (May 2009), pp. 3850-3855, ISSN: 0008-5472

Hoeijmakers, J.H. (2001). Genome maintenance mechanisms for preventing cancer. Nature, Vol. 411, No.6835, (May 2001), pp. 366-374, ISSN: 0028-0836

Hotz, H.G., Hines, O.J., Masood, R., Hotz, B., Foitzik, T., Buhr, H.J., Gill, P.S. \& Reber, H.A. (2005). VEGF antisense therapy inhibits tumor growth and improves survival in experimental pancreatic cancer. Surgery, Vol. 137, No.2, (February 2005), pp. $192-$ 199, ISSN: 0039-6060

Hruban, R.H. (2001). Pancreatic cancer: from genes to patient care. J Gastrointest Surg, Vol. 5, No.6, (November-Dececember 2001), pp. 583-587, ISSN: 1091-255X 
Huang, Y., Shen, X.J., Zou, Q., Wang, S.P., Tang, S.M. \& Zhang, G.Z. (2011). Biological functions of microRNAs: a review. Journal of Physiology and Biochemistry, Vol. 67, No.1, (March 2011), pp. 129-139, ISSN: 1877-8755

Huntzinger, E. \& Izaurralde, E. (2011). Gene silencing by microRNAs: contributions of translational repression and mRNA decay. Nat Rev Genet, Vol. 12, No.2, (February 2011), pp. 99-110, ISSN: 1471-0056

Hwang, J.H., Voortman, J., Giovannetti, E., Steinberg, S.M., Leon, L.G., Kim, Y.T., Funel, N., Park, J.K., Kim, M.A., Kang, G.H., Kim, S.W., Del Chiaro, M., Peters, G.J. \& Giaccone, G. (2010). Identification of microRNA-21 as a biomarker for chemoresistance and clinical outcome following adjuvant therapy in resectable pancreatic cancer. PLoS One, Vol. 5, No.5, (May 2010), pp. e10630, ISSN: 1932-6203

Ignatiadis, M., Polyzos, A., Stathopoulos, G.P., Tselepatiotis, E., Christophylakis, C., Kalbakis, K., Vamvakas, L., Kotsakis, A., Potamianou, A. \& Georgoulias, V. (2006). A multicenter phase II study of docetaxel in combination with gefitinib in gemcitabine-pretreated patients with advanced/metastatic pancreatic cancer. Oncology, Vol. 71, No. 3-4, (August 2006), pp.159-63, ISSN: 0030-2414

Ingham, P.W. \& McMahon, A.P. (2001). Hedgehog signalling in animal development: paradigms and principles. Genes Dev, Vol. 15, No.23, (December 2001), pp. 30593087, ISSN: 0890-9369

Iorio, M.V. \& Croce, C.M. (2009). MicroRNAs in cancer: small molecules with a huge impact. J Clin Oncol, Vol. 27, No.34, (December 2009), pp. 5848-5856, ISSN: 0732-183X

Iwahashi, S., Shimada, M., Utsunomiya, T., Morine, Y., Imura, S., Ikemoto, T., Mori, H., Hanaoka, J., Sugimoto, K. \& Saito, Y. (2011). Histone deacetylase inhibitor augments anti-tumor effect of gemcitabine and pegylated interferon-alpha on pancreatic cancer cells. Int J Clin Oncol, (May 2011), pp. ISSN: 2547-7772

Jemal, A., Siegel, R., Xu, J. \& Ward, E. (2010). Cancer statistics, 2010. CA Cancer J Clin, Vol. 60, No.5, (September-October 2010), pp. 277-300, ISSN: 0007-9235

Jones, P.A. \& Baylin, S.B. (2007). The epigenomics of cancer. Cell, Vol. 128, No.4, (February 2007), pp. 683-692, ISSN: 0092-8674

Jones, S., Zhang, X., Parsons, D.W., Lin, J.C., Leary, R.J., Angenendt, P., Mankoo, P., Carter, H., Kamiyama, H., Jimeno, A., Hong, S.M., Fu, B., Lin, M.T., Calhoun, E.S., Kamiyama, M., Walter, K., Nikolskaya, T., Nikolsky, Y., Hartigan, J., Smith, D.R., Hidalgo, M., Leach, S.D., Klein, A.P., Jaffee, E.M., Goggins, M., Maitra, A., Iacobuzio-Donahue, C., Eshleman, J.R., Kern, S.E., Hruban, R.H., Karchin, R., Papadopoulos, N., Parmigiani, G., Vogelstein, B., Velculescu, V.E. \& Kinzler, K.W. (2008). Core signalling pathways in human pancreatic cancers revealed by global genomic analyses. Science, Vol. 321, No.5897, (September 2008), pp. 1801-1806, ISSN: 0036-8075

Jones, S., Hruban, R.H., Kamiyama, M., Borges, M., Zhang, X., Parsons, D.W., Lin, J.C., Palmisano, E., Brune, K., Jaffee, E.M., Iacobuzio-Donahue, C.A., Maitra, A., Parmigiani, G., Kern, S.E., Velculescu, V.E., Kinzler, K.W., Vogelstein, B., Eshleman, J.R., Goggins, M. \& Klein, A.P. (2009). Exomic sequencing identifies PALB2 as a pancreatic cancer susceptibility gene. Science, Vol. 324, No.5924, (April 2009), pp. 217, ISSN: 0036-8075. 
Karkkainen, M.J., Makinen, T. \& Alitalo, K. (2002). Lymphatic endothelium: a new frontier of metastasis research. Nat Cell Biol, Vol. 4, No.1, (January 2002), pp. E2-5, ISSN: $1465-7392$

Kell, J. (2007). Drug evaluation: MGCD-0103, a histone deacetylase inhibitor for the treatment of cancer. Curr Opin Investig Drugs, Vol. 8, No.6, (June 2007), pp. 485-492, ISSN: $1472-4472$

Kent, O.A. \& Mendell, J.T. (2006). A small piece in the cancer puzzle: microRNAs as tumor suppressors and oncogenes. Oncogene, Vol. 25, No.46, (October 2006), pp. 61886196, ISSN: 1476-5594

Khan, S.B., Maududi, T., Barton, K., Ayers, J. \& Alkan, S. (2004). Analysis of histone deacetylase inhibitor, depsipeptide (FR901228), effect on multiple myeloma. $\mathrm{Br} \mathrm{J}$ Haematol, Vol. 125, No.2, (April 2004), pp. 156-161, ISSN: 0007-1048

Kindler, H.L., Richards, D.A., Stephenson, J., Garbo, L.E., Rocha Lima, C.S., Safran, H., Wiezorek, J.S., Feigal, E.G., Bray, S. \& Fuchs, C. (2010a). A placebo-controlled, randomized phase II study of conatumumab (C) or AMG 479 (A) or placebo (P) plus gemcitabine $(\mathrm{G})$ in patients (pts) with metastatic pancreatic cancer (mPC). Proceedings of the ASCO Annual Meeting, ISSN: 0732-183X, Chicago, June 2010

Kindler, H.L., Wroblewski, K., Wallace, J.A., Hall, M.J., Locker, G., Nattam, S., Agamah, E., Stadler, W.M. \& Vokes, E.E. (2010b). Gemcitabine plus sorafenib in patients with advanced pancreatic cancer: a phase II trial of the University of Chicago Phase II Consortium. Invest New Drugs, (August 2010), ISSN: 1573-0646

Kindler, H.L., Niedzwiecki, D., Hollis, D., Sutherland, S., Schrag, D., Hurwitz, H., Innocenti, F., Mulcahy, M.F., O'Reilly, E., Wozniak, T.F., Picus, J., Bhargava, P., Mayer, R.J., Schilsky, R.L. \& Goldberg, R.M. (2010c). Gemcitabine plus bevacizumab compared with gemcitabine plus placebo in patients with advanced pancreatic cancer: phase III trial of the Cancer and Leukemia Group B (CALGB 80303). J Clin Oncol, Vol. 28, No.22, (August 2010), pp. 3617-3622, ISSN: 0732-183X

Kinsella, T.J. (2009). Coordination of DNA mismatch repair and base excision repair processing of chemotherapy and radiation damage for targeting resistant cancers. Clin Cancer Res, Vol. 15, No.6, (March 2009), pp. 1853-1859, ISSN: 1078-0432

Koniaras, K., Cuddihy, A.R., Christopoulos, H., Hogg, A. \& O'Connell, M.J. (2001). Inhibition of Chk1-dependent G2 DNA damage checkpoint radiosensitizes p53 mutant human cells. Oncogene, Vol. 20, No.51, (November 2001), pp. 7453-7463, ISSN: 0950-9232

Kota, J., Chivukula, R.R., O'Donnell, K.A., Wentzel, E.A., Montgomery, C.L., Hwang, H.W., Chang, T.C., Vivekanandan, P., Torbenson, M., Clark, K.R., Mendell, J.R. \& Mendell, J.T. (2009). Therapeutic microRNA delivery suppresses tumorigenesis in a murine liver cancer model. Cell, Vol. 137, No.6, (June 2009), pp. 1005-1017, ISSN: 0092-8674

Kuehn, R., Lelkes, P.I., Bloechle, C., Niendorf, A. \& Izbicki, J.R. (1999). Angiogenesis, angiogenic growth factors, and cell adhesion molecules are upregulated in chronic pancreatic diseases: angiogenesis in chronic pancreatitis and in pancreatic cancer. Pancreas, Vol. 18, No.1, (January 1999), pp. 96-103, ISSN: 0885-3177

Kurz, E.U. \& Lees-Miller, S.P. (2004). DNA damage-induced activation of ATM and ATMdependent signalling pathways. DNA Repair (Amst), Vol. 3, No.8-9, (AugustSeptember 2004), pp. 889-900, ISSN: 1568-7856 
Lee, J.H., Choy, M.L., Ngo, L., Foster, S.S. \& Marks, P.A. (2010). Histone deacetylase inhibitor induces DNA damage, which normal but not transformed cells can repair. Proc Natl Acad Sci U S A, Vol. 107, No.33, (August 2010), pp. 14639-14644, ISSN: 0027-8424

Lee, R.C., Feinbaum, R.L. \& Ambros, V. (1993). The C. elegans heterochronic gene lin-4 encodes small RNAs with antisense complementarity to lin-14. Cell, Vol. 75, No.5, (December 1993), pp. 843-854, ISSN: 0092-8674

Lemoine, N.R., Hughes, C.M., Barton, C.M., Poulsom, R., Jeffery, R.E., Kloppel, G., Hall, P.A. \& Gullick, W.J. (1992). The epidermal growth factor receptor in human pancreatic cancer. J Pathol, Vol. 166, No.1, (January 1992), pp. 7-12, ISSN: 0022-3417

Li, G.M. (2008). Mechanisms and functions of DNA mismatch repair. Cell Res, Vol. 18, No.1, (January 2008), pp. 85-98, ISSN: 1001-0602

Liffers, S.T., Munding, J.B., Vogt, M., Kuhlmann, J.D., Verdoodt, B., Nambiar, S., Maghnouj, A., Mirmohammadsadegh, A., Hahn, S.A. \& Tannapfel, A. (2011). MicroRNA-148a is down-regulated in human pancreatic ductal adenocarcinomas and regulates cell survival by targeting CDC25B. Lab Invest, (June 2011), ISSN: 1530-0307 (Electronic)

Lindahl, T. (1993). Instability and decay of the primary structure of DNA. Nature, Vol. 362, No.6422, (April 1993), pp. 709-715, ISSN: 0028-0836

Ma, C.X., Janetka, J.W. \& Piwnica-Worms, H. (2011). Death by releasing the breaks: CHK1 inhibitors as cancer therapeutics. Trends Mol Med, Vol. 17, No.2, (February 2011), pp. 88-96, ISSN: 1471-4914

Ma, W.W. \& Adjei, A.A. (2009). Novel agents on the horizon for cancer therapy. CA Cancer J Clin, Vol. 59, No.2, (March-April 2009), pp. 111-137, ISSN: 0007-9235

Mallardo, M., Poltronieri, P. \& D'Urso, O.F. (2008). Non-protein coding RNA biomarkers and differential expression in cancers: a review. J Exp Clin Cancer Res, Vol. 27, No. 1, (July 2008), pp. 19, ISSN: 1756-9966

Martin, S.T., Sato, N., Dhara, S., Chang, R., Hustinx, S.R., Abe, T., Maitra, A. \& Goggins, M. (2005). Aberrant methylation of the Human Hedgehog interacting protein (HHIP) gene in pancreatic neoplasms. Cancer Biol Ther, Vol. 4, No.7, (July 2005), pp. 728733, ISSN: 1538-4047

Matsuda, K., Idezawa, T., You, X.J., Kothari, N.H., Fan, H. \& Korc, M. (2002). Multiple mitogenic pathways in pancreatic cancer cells are blocked by a truncated epidermal growth factor receptor. Cancer Res, Vol. 62, No.19, (October 2002), pp. 5611-5617, ISSN: 0008-5472

McCabe, N., Lord, C.J., Tutt, A.N., Martin, N.M., Smith, G.C. \& Ashworth, A. (2005). BRCA2-deficient CAPAN-1 cells are extremely sensitive to the inhibition of Poly (ADP-Ribose) polymerase: an issue of potency. Cancer Biol Ther, Vol. 4, No.9, (September 2005), pp. 934-936, ISSN: 1538-4047

Medina, P.P. \& Slack, F.J. (2008). microRNAs and cancer: an overview. Cell Cycle, Vol. 7, No.16, (August 2008), pp. 2485-2492, ISSN: 1551-4005

Meek, K., Gupta, S., Ramsden, D.A. \& Lees-Miller, S.P. (2004). The DNA-dependent protein kinase: the director at the end. Immunol Rev, Vol. 200, No. 1, (August 2004), pp. 132141, ISSN: 0105-2896

Moore, M.J., Goldstein, D., Hamm, J., Figer, A., Hecht, J.R., Gallinger, S., Au, H.J., Murawa, P., Walde, D., Wolff, R.A., Campos, D., Lim, R., Ding, K., Clark, G., VoskoglouNomikos, T., Ptasynski, M. \& Parulekar, W. (2007). Erlotinib plus gemcitabine 
compared with gemcitabine alone in patients with advanced pancreatic cancer: a phase III trial of the National Cancer Institute of Canada Clinical Trials Group. J Clin Oncol, Vol. 25, No.15, (May 2007), pp. 1960-1966, ISSN: 0732-183X

Morgan, M.A., Parsels, L.A., Zhao, L., Parsels, J.D., Davis, M.A., Hassan, M.C., Arumugarajah, S., Hylander-Gans, L., Morosini, D., Simeone, D.M., Canman, C.E., Normolle, D.P., Zabludoff, S.D., Maybaum, J. \& Lawrence, T.S. (2010). Mechanism of radiosensitization by the Chk1/2 inhibitor AZD7762 involves abrogation of the G2 checkpoint and inhibition of homologous recombinational DNA repair. Cancer Res, Vol. 70, No.12, (June 2010), pp. 4972-4981, ISSN: 0008-5472

Morton, J.P., Mongeau, M.E., Klimstra, D.S., Morris, J.P., Lee, Y.C., Kawaguchi, Y., Wright, C.V., Hebrok, M. \& Lewis, B.C. (2007). Sonic hedgehog acts at multiple stages during pancreatic tumorigenesis. Proc Natl Acad Sci U S A, Vol. 104, No.12, (March 2007), pp. 5103-5108, ISSN: 0027-8424

Moss, E.G. (2007). Heterochronic Genes and the Nature of Developmental Time. Current Biology, Vol. 17, No.11, (June 2007), pp. R425-R434, ISSN: 09609822

Nana-Sinkam, S.P. \& Croce, C.M. (2011). MicroRNAs as therapeutic targets in cancer. Translational Research, Vol. 157, No.4, (April 2011), pp. 216-225, ISSN: 19315244

Natoli, C., Perrucci, B., Perrotti, F., Falchi, L., Iacobelli, S.; Consorzio Interuniversitario Nazionale per Bio-Oncologia (CINBO). (2010). Tyrosine kinase inhibitors. Curr Cancer Drug Targets, Vol. 10, No. 5, (August 2010), pp. 462-483, ISSN: 1568-0096

Ng, S.S., Tsao, M.S., Nicklee, T. \& Hedley, D.W. (2002). Effects of the epidermal growth factor receptor inhibitor OSI-774, Tarceva, on downstream signalling pathways and apoptosis in human pancreatic adenocarcinoma. Mol Cancer Ther, Vol. 1, No.10, (August 2002), pp. 777-783, ISSN: 1535-7163

Orom, U.A., Derrien, T., Beringer, M., Gumireddy, K., Gardini, A., Bussotti, G., Lai, F., Zytnicki, M., Notredame, C., Huang, Q., Guigo, R. \& Shiekhattar, R. (2010). Long noncoding RNAs with enhancer-like function in human cells. Cell, Vol. 143, No.1, (October 2010), pp. 46-58, ISSN: 0092-8674

Osaki, M., Oshimura, M. \& Ito, H. (2004). PI3K-Akt pathway: its functions and alterations in human cancer. Apoptosis, Vol. 9, No.6, (November 2004), pp. 667-676, ISSN: 13608185

Ouaissi, M., Sielezneff, I., Silvestre, R., Sastre, B., Bernard, J.P., Lafontaine, J.S., Payan, M.J., Dahan, L., Pirro, N., Seitz, J.F., Mas, E., Lombardo, D. \& Ouaissi, A. (2008). High histone deacetylase 7 (HDAC7) expression is significantly associated with adenocarcinomas of the pancreas. Ann Surg Oncol, Vol. 15, No.8, (August 2008), pp. 2318-2328, ISSN: 1068-9265

Ouaissi, M., Giger, U., Sielezneff, I., Pirro, N., Sastre, B. \& Ouaissi, A. (2011). Rationale for possible targeting of histone deacetylase signalling in cancer diseases with a special reference to pancreatic cancer. J Biomed Biotechnol, Vol. 2011, ISSN: 1110-7251

Pani, E., Stojic, L., El-Shemerly, M., Jiricny, J. \& Ferrari, S. (2007). Mismatch repair status and the response of human cells to cisplatin. Cell Cycle, Vol. 6, No.14, (July 2007), pp. 1796-1802, ISSN: 1551-4005

Park, J.K., Lee, E.J., Esau, C. \& Schmittgen, T.D. (2009). Antisense inhibition of microRNA-21 or -221 arrests cell cycle, induces apoptosis, and sensitizes the effects of gemcitabine in pancreatic adenocarcinoma. Pancreas, Vol. 38, No.7, (October 2009), pp. e190-199, ISSN: 0885-3177 
Parsels, L.A., Qian, Y., Tanska, D.M., Gross, M., Zhao, L., Hassan, M.C., Arumugarajah, S., Parsels, J.D., Hylander-Gans, L., Simeone, D.M., Morosini, D., Brown, J.L., Zabludoff, S.D., Maybaum, J., Lawrence, T.S. \& Morgan, M.A. (2011). Assessment of chk1 phosphorylation as a pharmacodynamic biomarker of chk1 inhibition. Clin Cancer Res, Vol. 17, No.11, (June 2011), pp. 3706-3715, ISSN: 1078-0432

Pene, F., Courtine, E., Cariou, A. \& Mira, J.P. (2009). Toward theragnostics. Crit Care Med, Vol. 37, No.1 Suppl, (January 2009), pp. S50-58, ISSN: 0090-3493

Perugini, R.A., McDade, T.P., Vittimberga, F.J., Jr. \& Callery, M.P. (2000). Pancreatic cancer cell proliferation is phosphatidylinositol 3-kinase dependent. J Surg Res, Vol. 90, No.1, (May 2000), pp. 39-44, ISSN: 0022-4804

Philip, P.A., Benedetti, J., Corless, C.L., Wong, R., O'Reilly, E.M., Flynn, P.J., Rowland, K.M., Atkins, J.N., Mirtsching, B.C., Rivkin, S.E., Khorana, A.A., Goldman, B., FenoglioPreiser, C.M., Abbruzzese, J.L. \& Blanke, C.D. (2010). Phase III study comparing gemcitabine plus cetuximab versus gemcitabine in patients with advanced pancreatic adenocarcinoma: Southwest Oncology Group-directed intergroup trial S0205. J Clin Oncol, Vol. 28, No.22, (August 2010), pp. 3605-3610, ISSN: 0732-183X

Pishvaian, M.J., Slack, R., Witkiewicz, A., He, A.R., Hwang, J.J., Hankin, A., Ley, L., Apte, S.K., Littman, S.J., Weiner, L.M., Marshall, J. \& Brody, J.R. (2011). A phase I/II study of the PARP inhibitor, ABT-888 plus 5-fluorouracil and oxaliplatin (modified FOLFOX-6) in patients with metastatic pancreatic cancer. Proceedings of the ASCO Annual Meeting, ISSN: 0732-183X, Chicago, June 2011

Ramos, J.W. (2008). The regulation of extracellular signal-regulated kinase (ERK) in mammalian cells. Int J Biochem Cell Biol, Vol. 40, No.12, pp. 2707-2719, ISSN: 13572725

Richards, D.A., Kuefler, P.R., Becerra, C., Wilfong, L.S., Gersh, R.H., Boehm, K.A., Zhan, F., Asmar, L., Myrand, S.P., Hozak, R.R., Zhao, L., Gill, J.F., Mullaney, B.P., Obasaju, C.K. \& Nicol, S.J. (2011). Gemcitabine plus enzastaurin or single-agent gemcitabine in locally advanced or metastatic pancreatic cancer: results of a phase II, randomized, noncomparative study. Invest New Drugs, Vol. 29, No.1, (February 2011), pp. 144-153, ISSN: 0167-6997

Rinehart, J., Adjei, A.A., Lorusso, P.M., Waterhouse, D., Hecht, J.R., Natale, R.B., Hamid, O., Varterasian, M., Asbury, P., Kaldjian, E.P., Gulyas, S., Mitchell, D.Y., Herrera, R., Sebolt-Leopold, J.S. \& Meyer, M.B. (2004). Multicenter phase II study of the oral MEK inhibitor, CI-1040, in patients with advanced non-small-cell lung, breast, colon, and pancreatic cancer. J Clin Oncol, Vol. 22, No.22, (November 2004), pp. 4456-4462, ISSN: 0732-183X

Ruiz i Altaba, A., Sanchez, P. \& Dahmane, N. (2002). Gli and hedgehog in cancer: tumours, embryos and stem cells. Nat Rev Cancer, Vol. 2, No.5, (May 2002), pp. 361-372, ISSN: 1474-175X

Safran, H., Iannitti, D., Ramanathan, R., Schwartz, J.D., Steinhoff, M., Nauman, C., Hesketh, P., Rathore, R., Wolff, R., Tantravahi, U., Hughes, T.M., Maia, C., Pasquariello, T., Goldstein, L., King, T., Tsai, J.Y. \& Kennedy, T. (2004). Herceptin and gemcitabine for metastatic pancreatic cancers that overexpress HER-2/neu. Cancer Invest, Vol. 22, No.5, pp. 706-712, ISSN: 0735-7907

Safran, H., Miner, T., Resnick, M., Dipetrillo, T., McNulty, B., Evans, D., Joseph, P., Plette, A., Millis, R., Sears, D., Gutman, N. \& Kennedy, T. Lapatinib/gemcitabine and 
lapatinib/gemcitabine/oxaliplatin: a phase I study for advanced pancreaticobiliary cancer. Am J Clin Oncol, Vol. 31, No. 2, (April 2008), pp. 140-4, ISSN: 0277-3732

Schlieman, M.G., Fahy, B.N., Ramsamooj, R., Beckett, L. \& Bold, R.J. (2003). Incidence, mechanism and prognostic value of activated AKT in pancreas cancer. $\mathrm{Br} J$ Cancer, Vol. 89, No.11, (December 2003), pp. 2110-2115, ISSN: 0007-0920

Seo, Y., Baba, H., Fukuda, T., Takashima, M. \& Sugimachi, K. (2000). High expression of vascular endothelial growth factor is associated with liver metastasis and a poor prognosis for patients with ductal pancreatic adenocarcinoma. Cancer, Vol. 88, No.10, (May 2000), pp. 2239-2245, ISSN: 0008-543X

Shah, A.N. \& Gallick, G.E. (2007). Src, chemoresistance and epithelial to mesenchymal transition: are they related? Anticancer Drugs, Vol. 18, No.4, (April 2007), pp. 371375, ISSN: 0959-4973

Shi, C., Hruban, R.H. \& Klein, A.P. (2009). Familial pancreatic cancer. Arch Pathol Lab Med, Vol. 133, No.3, (March 2009), pp. 365-374, ISSN: 0003-9985

Sigalotti, L., Fratta, E., Coral, S., Cortini, E., Covre, A., Nicolay, H.J., Anzalone, L., Pezzani, L., Di Giacomo, A.M., Fonsatti, E., Colizzi, F., Altomonte, M., Calabro, L. \& Maio, M. (2007). Epigenetic drugs as pleiotropic agents in cancer treatment: biomolecular aspects and clinical applications. J Cell Physiol, Vol. 212, No.2, (August 2007), pp. 330-344, ISSN: 0021-9541

Siomi, M.C., Sato, K., Pezic, D. \& Aravin, A.A. (2011). PIWI-interacting small RNAs: the vanguard of genome defence. Nat Rev Mol Cell Biol, Vol. 12, No.4, (April 2011), pp. 246-258, ISSN: 1471-0072

Sonnenblick, A., Kadouri, L., Appelbaum, L., Peretz, T., Sagi, M., Goldberg, Y. \& Hubert, A. (2011). Complete remission, in BRCA2 mutation carrier with metastatic pancreatic adenocarcinoma, treated with cisplatin based therapy. Cancer Biol Ther, Vol. 12, No.3, (August 2011), pp. 165-168, ISSN: 1538-4047

Spano, J.P., Chodkiewicz, C., Maurel, J., Wong, R., Wasan, H., Barone, C., Letourneau, R., Bajetta, E., Pithavala, Y., Bycott, P., Trask, P., Liau, K., Ricart, A.D., Kim, S. \& Rixe, O. (2008). Efficacy of gemcitabine plus axitinib compared with gemcitabine alone in patients with advanced pancreatic cancer: an open-label randomised phase II study. Lancet, Vol. 371, No.9630, (Junu 2008), pp. 2101-2108, ISSN: 0140-6736

Sung, V., Richard, N., Brady, H., Maier, A., Kelter, G. \& Heise, C. (2011). Histone deacetylase inhibitor MGCD0103 synergizes with gemcitabine in human pancreatic cells. Cancer Sci, Vol. 102, No.6, (June 2011), pp. 1201-1207, ISSN: 1347-9032

Tanno, S., Mitsuuchi, Y., Altomare, D.A., Xiao, G.H. \& Testa, J.R. (2001). AKT activation upregulates insulin-like growth factor I receptor expression and promotes invasiveness of human pancreatic cancer cells. Cancer Res, Vol. 61, No.2, (January 2001), pp. 589-593, ISSN: 0008-5472

Terman, B.I., Dougher-Vermazen, M., Carrion, M.E., Dimitrov, D., Armellino, D.C., Gospodarowicz, D. \& Bohlen, P. (1992). Identification of the KDR tyrosine kinase as a receptor for vascular endothelial cell growth factor. Biochem Biophys Res Commun, Vol. 187, No.3, (September 1992), pp. 1579-1586, ISSN: 0006-291X

Tischkowitz, M.D., Sabbaghian, N., Hamel, N., Borgida, A., Rosner, C., Taherian, N., Srivastava, A., Holter, S., Rothenmund, H., Ghadirian, P., Foulkes, W.D. \& Gallinger, S. (2009). Analysis of the gene coding for the BRCA2-interacting protein 
PALB2 in familial and sporadic pancreatic cancer. Gastroenterology, Vol. 137, No.3, (September 2009), pp. 1183-1186, ISSN: 0016-5085

Tomillero, A. \& Moral, M.A. (2010). Gateways to clinical trials. Methods Find Exp Clin Pharmacol, Vol. 32, No.1, (January-February 2010), pp. 47-86, ISSN: 0379-0355

Tuli, R., Surmak, A. Jr., Blackford, A., Leubner, A., Jaffee, E.M., DeWeese, T.L. \& Herman, J.M. (2011). Effect of inhibition of poly-(ADP ribose) polymerase on gemcitabine and radiation-induced cytotoxicity of pancreatic cancer cells. Proceedings of the ASCO Annual Meeting, ISSN: 0732-183X, Chicago, June 2011

Van Cutsem, E., Aerts, R., Haustermans, K., Topal, B., Van Steenbergen, W. \& Verslype, C. (2004a). Systemic treatment of pancreatic cancer. Eur J Gastroenterol Hepatol, Vol. 16, No.3, (March 2004), pp. 265-274, ISSN: 0954-691X

Van Cutsem, E., van de Velde, H., Karasek, P., Oettle, H., Vervenne, W.L., Szawlowski, A.,Schoffski, P., Post, S., Verslype, C., Neumann, H., Safran, H., Humblet, Y., Perez Ruixo, J., Ma, Y. \& Von Hoff, D. (2004b). Phase III trial of gemcitabine plus tipifarnib compared with gemcitabine plus placebo in advanced pancreatic cancer. J Clin Oncol, Vol. 15, No. 8, (April 2004), pp. 1430-8, ISSN: 0732-183X

Van Cutsem, E., Vervenne, W.L., Bennouna, J., Humblet, Y., Gill, S., Van Laethem, J.L., Verslype, C., Scheithauer, W., Shang, A., Cosaert, J. \& Moore, M.J. (2009). Phase III trial of bevacizumab in combination with gemcitabine and erlotinib in patients with metastatic pancreatic cancer. J Clin Oncol, Vol. 27, No.13, (May 2009), pp. 22312237, ISSN: 0732-183X

van der Heijden, M.S., Brody, J.R., Dezentje, D.A., Gallmeier, E., Cunningham, S.C., Swartz, M.J., DeMarzo, A.M., Offerhaus, G.J., Isacoff, W.H., Hruban, R.H. \& Kern, S.E. (2005). In vivo therapeutic responses contingent on Fanconi anemia/BRCA2 status of the tumor. Clin Cancer Res, Vol. 11, No.20, (October 2005), pp. 7508-7515, ISSN: 1078-0432

Vrana, J.A., Decker, R.H., Johnson, C.R., Wang, Z., Jarvis, W.D., Richon, V.M., Ehinger, M., Fisher, P.B. \& Grant, S. (1999). Induction of apoptosis in U937 human leukemia cells by suberoylanilide hydroxamic acid (SAHA) proceeds through pathways that are regulated by $\mathrm{Bcl}-2 / \mathrm{Bcl}-\mathrm{XL}$, c-Jun, and p21CIP1, but independent of p53. Oncogene, Vol. 18, No.50, (November 1999), pp. 7016-7025, ISSN: 0950-9232

Wang, J., Lu, Z., Wientjes, M.G. \& Au, J.L. (2010). Delivery of siRNA therapeutics: barriers and carriers. AAPS J, Vol. 12, No.4, (December 2010), pp. 492-503, ISSN: 1550-7416

Wang, Z., Li, Y., Ahmad, A., Banerjee, S., Azmi, A.S., Kong, D. \& Sarkar, F.H. (2011). Pancreatic cancer: understanding and overcoming chemoresistance. Nat Rev Gastroenterol Hepatol, Vol. 8, No.1, (January 2011), pp. 27-33, ISSN: 1759-5045

Wolpin, B.M., Hezel, A.F., Abrams, T., Blaszkowsky, L.S., Meyerhardt, J.A., Chan, J.A., Enzinger, P.C., Allen, B., Clark, J.W., Ryan, D.P. \& Fuchs, C.S. (2009). Oral mTOR inhibitor everolimus in patients with gemcitabine-refractory metastatic pancreatic cancer. J Clin Oncol, Vol. 27, No.2, (January 2009), pp. 193-198, ISSN: 0732-183X

$\mathrm{Xu}$, W.S., Parmigiani, R.B. \& Marks, P.A. (2007). Histone deacetylase inhibitors: molecular mechanisms of action. Oncogene, Vol. 26, No.37, (August 2007), pp. 5541-5552, ISSN: 0950-9232

Yamanaka, Y., Friess, H., Kobrin, M.S., Buchler, M., Beger, H.G. \& Korc, M. (1993a). Coexpression of epidermal growth factor receptor and ligands in human pancreatic 
cancer is associated with enhanced tumor aggressiveness. Anticancer Res, Vol. 13, No.3, (May-June 1993), pp. 565-569, ISSN: 0250-7005

Yamanaka, Y., Friess, H., Kobrin, M.S., Buchler, M., Kunz, J., Beger, H.G. \& Korc, M. (1993b). Overexpression of HER2/neu oncogene in human pancreatic carcinoma. Hum Pathol, Vol. 24, No.10, (October 1993), pp. 1127-1134, ISSN: 0046-8177

Yang, H., Li, Q., Fan, J., Holloman, W.K. \& Pavletich, N.P. (2005). The BRCA2 homologue Brh2 nucleates RAD51 filament formation at a dsDNA-ssDNA junction. Nature, Vol. 433, No.7026, (February 2005), pp. 653-657, ISSN: 0028-0836

Yip-Schneider, M.T. \& Schmidt, C.M. (2003). MEK inhibition of pancreatic carcinoma cells by U0126 and its effect in combination with sulindac. Pancreas, Vol. 27, No.4, (November 2003), pp. 337-344, ISSN: 0885-3177

Yu, D.S., Sonoda, E., Takeda, S., Huang, C.L., Pellegrini, L., Blundell, T.L. \& Venkitaraman, A.R. (2003). Dynamic control of Rad51 recombinase by self-association and interaction with BRCA2. Mol Cell, Vol. 12, No.4, (October 2003), pp. 1029-1041, ISSN: 1097-2765

Zhang, L., Jamaluddin, M.S., Weakley, S.M., Yao, Q. \& Chen, C. (2011). Roles and Mechanisms of MicroRNAs in Pancreatic Cancer. World J Surg, Vol. 35, No.8, (August 2011), pp. 1725-1731, ISSN: 0364-2313

Zhong, Q., Chen, C.F., Li, S., Chen, Y., Wang, C.C., Xiao, J., Chen, P.L., Sharp, Z.D. \& Lee, W.H. (1999). Association of BRCA1 with the hRad50-hMre11-p95 complex and the DNA damage response. Science, Vol. 285, No.5428, (July1999), pp. 747-750, ISSN: 0036-8075 


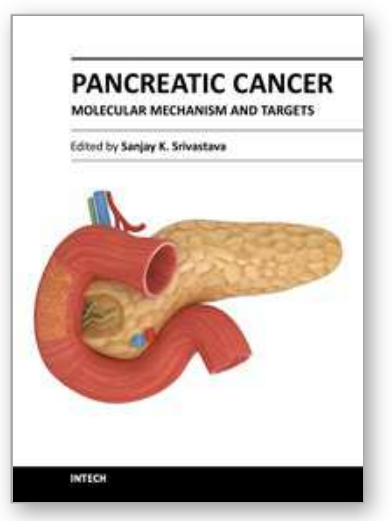

\author{
Pancreatic Cancer - Molecular Mechanism and Targets \\ Edited by Prof. Sanjay Srivastava
}

ISBN 978-953-51-0410-0

Hard cover, 432 pages

Publisher InTech

Published online 23, March, 2012

Published in print edition March, 2012

This book provides the reader with an overall understanding of the biology of pancreatic cancer, hereditary, complex signaling pathways and alternative therapies. The book explains nutrigenomics and epigenetics mechanisms such as DNA methylation, which may explain the etiology or progression of pancreatic cancer. Book also summarizes the molecular control of oncogenic pathways such as K-Ras and KLF4. Since pancreatic cancer metastasizes to vital organs resulting in poor prognosis, special emphasis is given to the mechanism of tumor cell invasion and metastasis. Role of nitric oxide and Syk kinase in tumor metastasis is discussed in detail. Prevention strategies for pancreatic cancer are also described. The molecular mechanisms of the anti-cancer effects of curcumin, benzyl isothiocyante and vitamin $D$ are discussed in detail. Furthermore, this book covers the basic mechanisms of resistance of pancreatic cancer to chemotherapy drugs such as gemcitabine and 5 -flourouracil.

\title{
How to reference
}

In order to correctly reference this scholarly work, feel free to copy and paste the following:

Nicola Tinari, Michele De Tursi, Antonino Grassadonia, Marinella Zilli, Stefano lacobelli and Clara Natoli (2012). New Targets for Therapy in Pancreatic Cancer, Pancreatic Cancer - Molecular Mechanism and Targets, Prof. Sanjay Srivastava (Ed.), ISBN: 978-953-51-0410-0, InTech, Available from:

http://www.intechopen.com/books/pancreatic-cancer-molecular-mechanism-and-targets/new-targets-inpancreatic-cancer-

\section{INTECH}

open science | open minds

\section{InTech Europe}

University Campus STeP Ri

Slavka Krautzeka 83/A

51000 Rijeka, Croatia

Phone: +385 (51) 770447

Fax: +385 (51) 686166

www.intechopen.com

\section{InTech China}

Unit 405, Office Block, Hotel Equatorial Shanghai

No.65, Yan An Road (West), Shanghai, 200040, China

中国上海市延安西路65号上海国际贵都大饭店办公楼405单元

Phone: +86-21-62489820

Fax: $+86-21-62489821$ 
(C) 2012 The Author(s). Licensee IntechOpen. This is an open access article distributed under the terms of the Creative Commons Attribution 3.0 License, which permits unrestricted use, distribution, and reproduction in any medium, provided the original work is properly cited. 